\title{
Studies on Betula essential oils
}

\author{
K. Hüsnü Can Başer* and Betül Demirci \\ Department of Pharmacognosy, Faculty of Pharmacy, Anadolu University, 26470-Eskişehir, \\ Turkey \\ E-mail: khcbaser@anadolu.edu.tr
}

Dedicated to Professor Atta-Ur-Rahman on the occasion of his $65^{\text {th }}$ birthday

\begin{abstract}
Essential oils were obtained from leaf, branch and buds of Betula species: $B$. pendula Roth, $B$. browicziana A.Güner, B. litwinowii Doluch., B. recurvata V. Vassil., and B. medwediewii Regel naturally growing in various parts of Turkey. Also buds of the common birch $B$. pendula essential oil from Germany and two species native to Finland namely, Betula pubescens ssp. czerepanovii (Orlova) Hämet-Ahti and Betula pubescens ssp. pubescens Erhr. were investigated. Betula essential oils were obtained by different distillation techniques such as hydrodistillation, microdistillation and Likens-Nickerson simultaneous distillation-extraction method (SDE). The resulting volatile compositions were elucidated by gas chromatography (GC) and gas chromatography-mass spectrometry (GC-MS) systems.

Known and new sesquiterpenes were isolated from Betula essential oils using column chromatographic techniques. Structure determination of each isolated compound was carried out using 1D and 2D NMR spectroscopic techniques supported by MS, UV and GC FITR.

Biological activities were determined both for essential oils and pure compounds isolated from the oils of Betula species. Antifungal, antibacterial and antioxidant activity results were carried out using various in vitro techniques.
\end{abstract}

Keywords: Betulaceae, Betula species, Birch tree, essential oil, sesquiterpenes, caryophyllene, chromato-spectral techniques, biological activity

\section{Introduction}

Well-known as birch tree, the genus Betula of the family Betulaceae, has a wide distribution in the northern hemisphere from Canada to Japan. ${ }^{1}$ Five Betula species, namely B. browicziana A. Güner, B. litwinowii Doluch., B. medwediewii Regel, B. pendula Roth and B. recurvata V. Vassil are naturally growing in eastern and northern Turkey, at high altitudes. Only B. browicziana is endemic to Turkey. ${ }^{2,3}$

The Birch tree has a long history of medicinal use in different countries and cultures to cure skin diseases especially eczema, infections, inflammations, rheumatism and urinary disorders. 
Betula bud oil is also widely used in cosmetic products as a tonic and antiseptic mainly in hair products. $^{4-7}$

Birch bark contains betulin, betulinol and a betuloside. The young leaves are rich in saponins and contain a diuretic flavonoid derivative (hyperoside), sesquiterpenes and tannins. The buds are rich in volatile oil. Birch tar contains creosol and guaiacol. ${ }^{5,8}$

The essential oils obtained from Betula species have been the subject of many investigations. $^{7-12}$ Betulenol, the main component of the oil, was isolated and reported from Betula buds and named first as betulol by Soden and Elze in 1905. Its structure was tentatively elucidated as a bicyclic primary sesquiterpene alcohol. Further investigations on this molecule were conducted by Triebs and other researchers as compiled in a work of Guenther. ${ }^{5}$ Afterwards Treibs and Lossner reported $\alpha$ - and $\beta$-betulenol, their acetates and $\alpha$-betulenal by means of synthesis to support the chemical structures present in the essential oil of Betula lenta. ${ }^{8}$ In contrast, Holub reported the occurrence of $\alpha$ - and $\beta$-betulenol, as well as $\alpha$-betulenol acetate with different structures as the previous investigators, also isolated from Betula species. ${ }^{9}$ Dhar et al. reviewed the chemistry of the birch tree including the essential oil which appeared to support Holubs' previous work. ${ }^{10}$ Hiltunen and co-workers reconfirmed by means of chemical reactions and gas chromatography / mass spectrometry (GC - MS), the occurrence of the main compounds as $\alpha$ - and $\beta$-betulenol and their relevant acetates in the bud oil of B. pubescens Ehrh., supporting Treibs' work. ${ }^{11}$

Essential oil components of B. pendula were analyzed by Stepen and co-workers using GC where the main components were identified as $\alpha$-betulenol acetate, caryophyllene and derivatives including low amounts of $\alpha$ - and $\beta$-betulenol. ${ }^{12}$ Kaneko et al. reported betulenols and their acetates in the essential oils isolated from the buds of nineteen Betula species. ${ }^{7}$ Studies on the essential oils and sesquiterpenes of Betula species growing in Turkey were subject to several studies by our group. ${ }^{13-18}$

This present work covers the essential oil chemistry as well as biological activities of the main components isolated from various Betula species investigated by our group.

\section{Results and Discussion}

Caryophyllene and its derivatives have been of special interest in the field of natural products chemistry and subjected to many detailed works and reviews. ${ }^{19-22}$ There have been many conflicts and disagreements concerning absolute configurations and structures of caryophyllene derivatives isolated from natural sources. ${ }^{7-9,23}$

The buds of $B$. pendula, B. litwinowii and B. medwediewii collected from various parts of Turkey were hydrodistilled while $B$. browicziana and $B$. recurvata buds were subjected to simultaneous distillation-extraction method (SDE) using a Likens-Nickerson apparatus due to limited plant material. The bud oils were analysed by GC-MS. The main component was isolated by Medium Pressure Liquid Chromatography (MPLC) in high purity. ${ }^{13,16}$ Literature search and comparison with spectral data ${ }^{23}$ confirmed the identity of this compound as 14-hydroxy- $\beta$ caryophyllene (1), which was found $20.5-37.5 \%$ in all investigated oils. 
In the light of the recent accumulated data, we propose that 14-hydroxy- $\beta$-caryophyllene is synonymous with $\alpha$-betulenol formerly isolated by Treibs from the bud essential oil of B. lenta ${ }^{8}$. The isolation of 14-hydroxy- $\beta$-caryophyllene (1) was also reported by Macleod ${ }^{24}$ from Pterocaulon serrulatum (Montr.) Guillaumin, an Australian plant, supporting the previously reported data. ${ }^{23,25}$

We acetylated 1 to form 14-acetoxy- $\beta$-caryophyllene (1a), ${ }^{13}$ which was also shown to be naturally present in Betula bud essential oils (0.1-0.8\%) by GC-MS (Scheme 1). Consequently, we suggest that 14 -acetoxy- $\beta$-caryophyllene (1a) is synonymous with $\alpha$-betulenol acetate, which was reported from $B$. lenta essential oil earlier. ${ }^{8}$

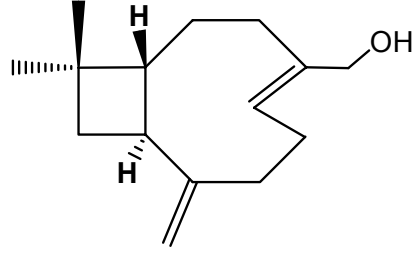

1

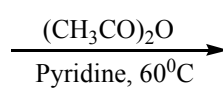

Scheme 1. Acetylation of 14-hydroxy- $\beta$-caryophyllene (1).

$\beta$-Betulenal (2) which was isolated by MPLC from Betula essential oils was also synthesized. ${ }^{13} \beta$-caryophyllene (3) was treated with $\mathrm{SeO}_{2}$, resulting in the formation of $\beta$ betulenal (2), 14-hydroxy-isocaryophyllene (4), and isocaryophyllene (5), as seen in Scheme 2. Compound $\mathbf{2}$ and $\mathbf{4}$ were isolated individually from the reaction mixture followed by structures confirmation by ${ }^{1} \mathrm{H}$ and ${ }^{13} \mathrm{C}$ NMR. This information supported that 14-hydroxy-isocaryophyllene (4) is synonymous with $\beta$-betulenol and $\beta$-betulenal (2) with isocaryophyllen-14-al, when compared with previous investigations. ${ }^{8}$ To ensure the proposal, $\mathbf{2}$ was subjected to a mild reduction with $\mathrm{NaBH}_{4}$, resulting in $\beta$-betulenol (4). These compounds were also detected in the Betula bud essential oils by GC-MS. Content of $\beta$-betulenol and $\beta$-betulenal, in the oils of investigated Betula species were found from trace to $1.2 \%$ and $2.0-5.2 \%$, respectively (Table 1 ).

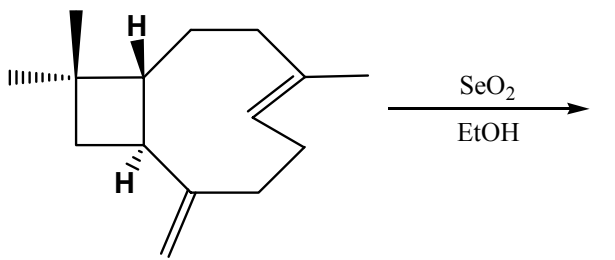

3

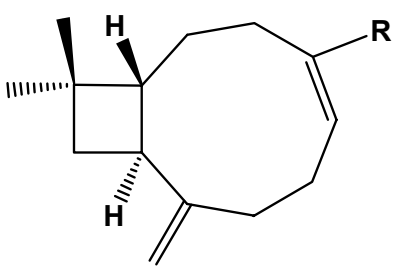

$2 \mathrm{R}=\mathrm{CHO}$

$4 \mathrm{R}=\mathrm{CH}_{2} \mathrm{OH}$

$5 \mathrm{R}=\mathrm{CH}_{3}$

Scheme 2. Oxidation of $\beta$-caryophyllene (3). 
Table 1. Main components of the different parts of Betula species growing in Turkey

\begin{tabular}{|c|c|c|c|c|c|c|c|c|c|c|c|c|c|c|c|c|}
\hline \multirow[t]{2}{*}{ RRI } & \multirow[t]{2}{*}{ Compound } & \multicolumn{3}{|c|}{$\begin{array}{c}\text { Betula pendula } \\
\%\end{array}$} & \multicolumn{3}{|c|}{$\begin{array}{c}\text { Betula browicziana } \\
\%\end{array}$} & \multicolumn{3}{|c|}{$\begin{array}{c}\text { Betula litwinowii } \\
\%\end{array}$} & \multicolumn{3}{|c|}{$\begin{array}{c}\text { Betula } \\
\text { medwediewii } \\
\% \\
\end{array}$} & \multicolumn{3}{|c|}{$\begin{array}{c}\text { Betula recurvata } \\
\%\end{array}$} \\
\hline & & $\mathrm{Br}$ & $\mathrm{L}$ & $\mathrm{B}$ & $\mathrm{Br}$ & $\mathrm{L}$ & $\mathrm{B}$ & $\mathrm{Br}$ & $\mathrm{L}$ & $\mathrm{B}$ & $\mathrm{Br}$ & $\mathrm{L}$ & $\mathrm{B}$ & $\mathrm{Br}$ & $\mathrm{L}$ & $\mathrm{B}$ \\
\hline 1093 & Hexanal & 0.1 & 0.1 & $\operatorname{tr}$ & 0.1 & 0.1 & $\operatorname{tr}$ & - & - & - & 0.1 & 0.5 & $\operatorname{tr}$ & - & 0.1 & - \\
\hline 1225 & (Z)-3-Hexenal & $\operatorname{tr}$ & 0.2 & $\operatorname{tr}$ & - & 0.4 & $\operatorname{tr}$ & - & $\operatorname{tr}$ & - & - & 5.8 & - & - & 0.4 & - \\
\hline 1360 & Hexanol & 0.1 & 0.1 & $\operatorname{tr}$ & 0.1 & 0.1 & $\operatorname{tr}$ & - & 0.2 & - & - & 1.4 & - & - & 0.2 & - \\
\hline 1400 & Nonanal & 0.2 & 0.1 & $\operatorname{tr}$ & 0.2 & 0.6 & 0.1 & - & 0.1 & - & 0.2 & 1.8 & 0.1 & $\operatorname{tr}$ & 0.2 & - \\
\hline 1412 & (E)-2-Hexenol & - & - & - & - & - & - & - & - & - & - & 0.7 & - & - & 0.1 & - \\
\hline 1553 & Linalool & 0.4 & 0.1 & $\operatorname{tr}$ & 0.3 & 0.5 & 0.1 & 0.5 & 1.0 & - & 0.3 & 2.8 & $\operatorname{tr}$ & 0.2 & 0.2 & - \\
\hline 1612 & $\beta$-Caryophyllene (3) & 2.9 & 1.4 & 3.9 & 2.4 & 0.3 & 4.9 & 0.8 & 1.1 & 1.3 & 0.1 & 0.4 & 1.2 & 0.2 & 1.3 & 3.2 \\
\hline 1687 & $\alpha$-Humulene & 4.3 & 2.0 & 6.8 & 3.8 & 0.3 & 3.7 & 0.8 & 0.7 & 1.6 & 0.2 & 0.2 & 2.3 & 0.3 & 1.7 & 5.6 \\
\hline 1706 & $\alpha$-Terpineol & 0.1 & $\operatorname{tr}$ & - & 0.1 & 0.1 & - & 0.2 & 0.3 & - & 0.1 & 0.5 & - & $\operatorname{tr}$ & 0.1 & - \\
\hline 1758 & $(\mathrm{E}, \mathrm{E})-\alpha-$-Farnesene & - & - & - & - & - & $\operatorname{tr}$ & 0.2 & 0.6 & - & - & 1.9 & $\operatorname{tr}$ & $\operatorname{tr}$ & 0.1 & - \\
\hline 1772 & Citronellol & 0.2 & $\operatorname{tr}$ & $\operatorname{tr}$ & 0.1 & 0.1 & $\operatorname{tr}$ & 0.3 & 0.7 & - & 0.6 & - & 0.1 & 0.1 & 0.1 & - \\
\hline 1798 & Methyl salicylate & $\operatorname{tr}$ & - & - & - & - & - & - & - & - & 67.8 & 49.8 & 0.3 & - & - & - \\
\hline 1802 & Cumin aldehyde & - & - & - & - & 0.8 & - & - & - & - & - & - & $\operatorname{tr}$ & - & - & - \\
\hline 1804 & Myrtenol & 0.2 & - & - & 0.7 & - & - & - & - & - & - & - & - & $\operatorname{tr}$ & $\operatorname{tr}$ & - \\
\hline 1834 & ethyl salicylate & - & - & - & - & - & - & - & - & - & 4.8 & 0.2 & - & - & - & - \\
\hline 1857 & Geraniol & 0.3 & 0.1 & 0.1 & 0.2 & 1.1 & $\operatorname{tr}$ & 0.4 & 2.0 & $\operatorname{tr}$ & 3.4 & 1.8 & 0.4 & 0.1 & 0.6 & $\operatorname{tr}$ \\
\hline 1958 & (E)- $\beta$-Ionone & - & 0.6 & - & 0.1 & 0.3 & - & - & 0.2 & - & 0.2 & 1.0 & - & - & $\operatorname{tr}$ & - \\
\hline 2008 & Caryophyllene oxide & 4.0 & 4.3 & 5.3 & 3.9 & 2.3 & 6.1 & 2.3 & 3.1 & 3.2 & 0.4 & 0.5 & 2.6 & 1.6 & 2.9 & 1.7 \\
\hline 2020 & $\begin{array}{l}\text { des-4-Methyl- } \\
\text { caryophyll-8(14)-en-5- } \\
\text { one (10) }\end{array}$ & 5.3 & 4.7 & 5.1 & 6.9 & 10.2 & 5.2 & 3.1 & 5.7 & 6.0 & 2.2 & 0.8 & 7.8 & 4.2 & 6.9 & 3.9 \\
\hline 2041 & Pentadecanal & - & - & - & - & - & - & - & - & - & 0.5 & 0.2 & 0.3 & - & - & - \\
\hline 2045 & Humulene epoxide-I & 0.5 & 0.3 & 0.6 & 0.6 & 0.2 & 0.3 & $\operatorname{tr}$ & 0.1 & 0.2 & - & - & 0.2 & 0.1 & 0.2 & 0.2 \\
\hline 2071 & Humulene epoxide-II & 4.9 & 4.8 & 6.9 & 3.9 & 2.4 & 4.2 & 1.4 & 1.5 & 3.3 & 0.4 & 0.4 & 3.1 & 1.3 & 2.6 & 2.4 \\
\hline 2092 & $\begin{array}{l}\text { 4,5-Dihydro- } \beta \text { - } \\
\text { caryophyllene-14-al (9) }\end{array}$ & 1.5 & 2.3 & 1.5 & 0.8 & 1.1 & 1.3 & 0.2 & 0.6 & 2.2 & 0.3 & 0.1 & 2.7 & 0.3 & 2.2 & 0.8 \\
\hline 2100 & Heneicosane & 0.6 & 0.1 & 0.4 & - & - & $\operatorname{tr}$ & 0.3 & 0.3 & - & 0.1 & - & 0.4 & 0.4 & - & - \\
\hline 2186 & Eugenol & 1.7 & 0.2 & 0.2 & 0.9 & 0.2 & 0.3 & - & - & 0.1 & 1.0 & 0.9 & 0.1 & - & 0.6 & $\operatorname{tr}$ \\
\hline 2193 & $\beta$-Betulenal (2) & 7.6 & 4.7 & 4.0 & 11.1 & 13.9 & 5.2 & 5.5 & 7.3 & 3.3 & 0.7 & 0.8 & 2.7 & 4.4 & 5.2 & 2.0 \\
\hline 2200 & Docosane & 0.1 & - & - & - & - & - & 0.2 & 1.1 & - & - & - & - & - & - & - \\
\hline 2239 & Carvacrol & - & $\operatorname{tr}$ & - & 2.6 & 2.5 & 0.1 & 0.2 & 0.1 & $\operatorname{tr}$ & 2.2 & 0.6 & 1.0 & 0.2 & 0.1 & $\operatorname{tr}$ \\
\hline 2272 & $\begin{array}{l}\text { 14-Acetoxy- } \beta \text { - } \\
\text { caryophyllene }\end{array}$ & 0.6 & 0.6 & 0.8 & 1.2 & 0.5 & 0.8 & 0.7 & 1.0 & 0.2 & $\operatorname{tr}$ & - & 0.1 & 3.7 & 2.3 & 0.5 \\
\hline
\end{tabular}

(1a)

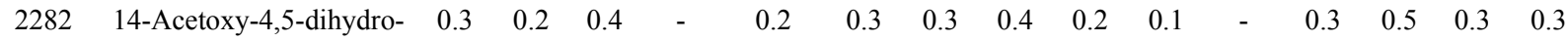
$\beta$-caryophyllene (8a)

2300 Tricosane

$1.0 \quad-\quad-\quad \begin{array}{llllllllllllllll} & 0.3 & - & - & 3.0 & 1.1 & - & 0.2 & 0.1 & 0.9 & 2.6 & - & -\end{array}$




\begin{tabular}{|c|c|c|c|c|c|c|c|c|c|c|c|c|c|c|c|c|}
\hline 2316 & $\begin{array}{l}\text { Caryophylla- } \\
\text { 4(14),8(15)-dien-5 } \beta \text {-ol } \\
\text { (=Caryophylladienol I) }\end{array}$ & 0.4 & 0.6 & 0.4 & 0.5 & 0.8 & 1.1 & 0.4 & 0.7 & 0.4 & - & 0.4 & 0.2 & 0.3 & 0.7 & 0.2 \\
\hline 2324 & $\begin{array}{l}\text { Caryophylla- } \\
4(14), 8(15) \text {-dien- } 5 \alpha-o l \\
\text { (=Caryophylladienol II) }\end{array}$ & 1.4 & 2.1 & 1.7 & 1.5 & 1.8 & 2.8 & 1.5 & 2.6 & 0.9 & $\operatorname{tr}$ & - & 0.6 & 1.0 & 2.1 & 0.6 \\
\hline 2329 & $\begin{array}{l}\text { 14-Acetoxy- } \alpha \text { - } \\
\text { humulene }\end{array}$ & 0.3 & 0.2 & 0.3 & - & - & - & 0.2 & 0.2 & 0.1 & - & - & 0.1 & 0.2 & 0.1 & 0.1 \\
\hline 2346 & $\begin{array}{l}\text { 6- } \\
\text { Hydroxycaryophyllene } \\
\text { (14) }\end{array}$ & 1.0 & 1.6 & 1.4 & 0.5 & 0.3 & 2.0 & 2.3 & 3.7 & 0.9 & - & - & 0.9 & 0.3 & 1.1 & 2.1 \\
\hline 2357 & $\begin{array}{l}\text { 14-Hydroxy- } \beta- \\
\text { caryophyllene } \\
\text { Betulenol })(\mathbf{1})\end{array} \quad(=\alpha-$ & 19.8 & 29.3 & 25.3 & 18.0 & 12.7 & 28.2 & 14.4 & 13.2 & 21.9 & 1.8 & 3.5 & 20.5 & 8.2 & 20.8 & 37.5 \\
\hline 2384 & Hexadecanol & - & - & - & - & 1.3 & - & - & 0.3 & - & - & 0.4 & - & - & 0.5 & - \\
\hline 2393 & $\begin{array}{l}\text { 14-Hydroxy- } \\
\text { isocaryophyllene } \quad(=\beta \text { - } \\
\text { Betulenol })(4)\end{array}$ & 0.9 & 1.3 & 1.2 & 1.3 & 1.1 & 1.0 & - & 0.6 & 0.6 & 0.2 & 0.1 & 0.8 & 0.4 & 0.5 & $\operatorname{tr}$ \\
\hline 2400 & Tetracosane & - & - & - & - & - & - & 0.7 & - & - & - & - & - & 0.2 & - & - \\
\hline 2415 & $\begin{array}{l}\text { 14-Hydroxy-4,5- } \\
\text { dihydro- } \beta \text { - } \\
\text { caryophyllene }(\mathbf{8})\end{array}$ & 13.4 & 21.4 & 17.2 & 14.3 & 24.8 & 16.0 & 19.1 & 18.5 & 36.8 & 4.2 & 3.7 & 27.6 & 22.7 & 25.2 & 23.8 \\
\hline 2478 & $\begin{array}{l}\text { 14-Hydroxy- } \alpha \text { - } \\
\text { humulene }\end{array}$ & 1.0 & 1.4 & 1.7 & 1.2 & 0.4 & 1.1 & 0.6 & 0.7 & 3.3 & 0.2 & - & 4.9 & 0.5 & 1.4 & 3.5 \\
\hline 2500 & Pentacosane & 5.3 & 1.3 & 0.5 & 1.3 & 2.0 & - & 13.6 & 3.6 & 0.4 & 0.2 & 1.2 & 1.6 & 13.3 & 1.2 & 0.2 \\
\hline 2609 & $\begin{array}{l}\text { 14-Hydroxy-4,5-epoxy- } \\
\beta \text {-caryophyllene }(\beta \beta) \\
\text { (7) }\end{array}$ & - & 0.2 & 0.2 & $\operatorname{tr}$ & - & 0.1 & - & - & - & - & - & - & - & 0.1 & - \\
\hline 2617 & $\begin{array}{l}\text { 14-Acetoxy-4,5-epoxy- } \\
\beta \text {-caryophyllene }(\beta \alpha) \\
\text { (6a) }\end{array}$ & - & - & $\operatorname{tr}$ & $\operatorname{tr}$ & - & - & - & - & - & - & - & - & - & 0.2 & - \\
\hline 2622 & Phytol & 0.1 & 0.2 & $\operatorname{tr}$ & 0.1 & 0.2 & - & 0.1 & 0.6 & - & - & 1.6 & 0.1 & 0.7 & 0.4 & - \\
\hline 2663 & $\begin{array}{l}\text { 14-Hydroxy-4,5-epoxy- } \\
\beta \text {-caryophyllene }(\beta \alpha) \\
\text { (6) }\end{array}$ & 0.2 & 0.9 & 1.3 & 0.3 & 0.2 & 0.4 & - & 0.3 & 0.9 & - & 0.1 & 0.3 & - & 0.5 & 0.7 \\
\hline 2700 & Heptacosane & 3.2 & 0.2 & 0.3 & 0.6 & 0.8 & - & 3.0 & 2.4 & - & 0.1 & 1.4 & 1.7 & 8.6 & 1.0 & - \\
\hline 2931 & Hexadecanoic acid & 0.4 & 0.2 & 0.1 & 1.0 & 0.4 & - & 0.9 & 0.5 & - & 0.1 & 3.1 & 0.1 & 1.0 & 0.1 & - \\
\hline
\end{tabular}

Br: Branch, L: Leaf, B: Bud

RRI Relative retention indices calculated against $n$-alkanes

$\%$ calculated from TIC data

tr Trace $(<0.1 \%)$ 
Manns and Hartmann reported (4E)-isocaryophyllen-14-al (= $\beta$-betulenal) in Cunila spicata Benth. (Lamiacea). ${ }^{26}$ Barrero et al. ${ }^{27}$ and Hiede et al. ${ }^{28}$ reported the presence of betulenal in Juniperus oxycedrus and $J$. virginiana essential oils without its configuration. Kaiser and Lamparsky ${ }^{29}$ assigned the structure of the aldehyde, formed in the reaction mixture by direct oxidation of caryophyllene with $\mathrm{SeO}_{2}$, as caryophyllen-14-al (= $\alpha$-betulenal), which was also detected in lavender oil.

With the same intention as above we acetylated 14-hydroxy-isocaryophyllene (4), resulting in the formation of 14-acetoxy-isocaryophyllene (= $\beta$-betulenol acetate) (4a). However, the acetate 4a was not detected in any Betula essential oils investigated in this study (Scheme 3).

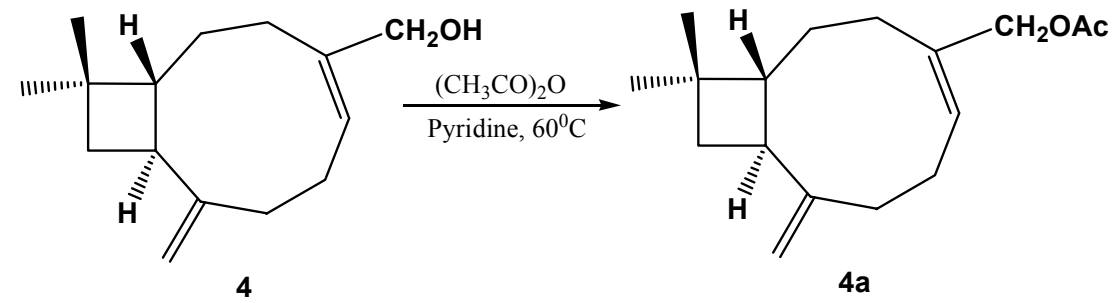

Scheme 3. Acetylation of 14-hydroxy-isocaryophyllene (4).

Furthermore, 14-hydroxy- $\beta$-caryophyllene (1) was epoxidized by $m$-CPBA resulting in the formation of the two synthetic diastereomeric epoxides namely, 14-hydroxy-4,5-epoxy- $\beta$ caryophyllene $(\beta \alpha)(6)$ and 14-hydroxy-4,5-epoxy- $\beta$-caryophyllene $(\beta \beta)(7)$, as shown in Scheme $4 .{ }^{16}$ These compounds were shown to be present in the investigated Betula essential oils (Table 1). 14-Hydroxy-4,5-epoxy- $\beta$-caryophyllene $(\beta \alpha)(6)$ was also obtained from the bud essential oil of $B$. pendula by MPLC. The acetate of this compound (6a) was shown to be present in the composition of the investigated Betula essential oils. The acetate of $\beta \beta$-form (7a) was also found in essential oil of B. recurvata leaves in trace amounts (Table 1).
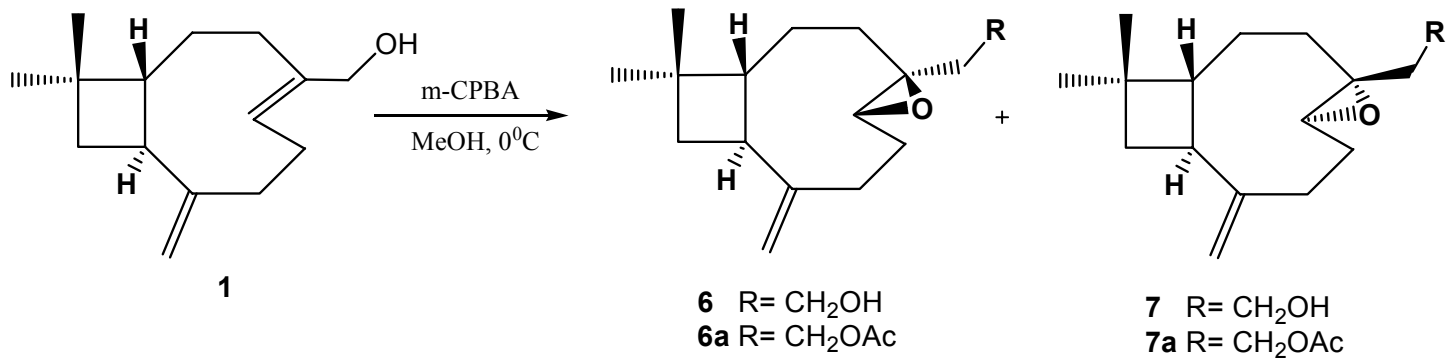

Scheme 4. Epoxidation of 14-hydroxy- $\beta$-caryophyllene (1).

In vitro antimicrobial activity evaluation against selected human pathogens Escherichia coli, Staphylococcus aureus, Micrococcus luteus, Pseudomonas aeruginosa, Bacillus cereus and the fungus Candida glabrata using 14-hydroxy- $\beta$-caryophyllene (1), 14-acetoxy- $\beta$-caryophyllene (1a), $\beta$-betulenal (2), $\beta$-caryophyllene (3), and 14-hydroxy-isocaryophyllene (4) were conducted. Chloramphenicol was used as reference and moderate activities were observed against Gram 
$(+) /(-)$ bacteria. Ketoconazole was used as antifungal reference against $C$. glabrata, where also moderate activity was observed. Antibacterial activity was shown against Streptococcus nutans, $S$. aureus and E. coli for caryophylla-4,8(13)-dien-6-ol, caryophylla-4,8(13)-dien-6-one, caryophylla-4,7-dien-6-one and caryophylla-3,8(13)-dien-5,6-diol isolated from $B$. pubescens, activities of which were said to be patented. ${ }^{30}$ Other antimicrobial investigations using different extracts of various Betula species have been conducted. ${ }^{31-34}$ Recently, 14-hydroxy- $\beta$ caryophyllene (1) was reported to have antibacterial activity against Bacillus subtilis and Escherichia coli. ${ }^{24}$

Our research into Betula species growing in Turkey has resulted in the isolation of new caryophyllene derivatives namely; 14 -hydroxy-4,5-dihydro- $\beta$-caryophyllene (8), 4,5-dihydro- $\beta$ caryophyllene-14-al (9), and des-4-methyl-caryophyll-8(14)-en-5-one (10) from B. litwinowii. ${ }^{15}$ 14-Acetoxy-4,5-dihydro- $\beta$-caryophyllene (8a) was prepared from 14-hydroxy-4,5-dihydro- $\beta$ caryophyllene (8) (Figure 1). 14-Acetoxy-4,5-dihydro- $\beta$-caryophyllene (8a) was also identified by GC-MS and retention index data to be identical to that present in the Betula essential oils (Table 1).

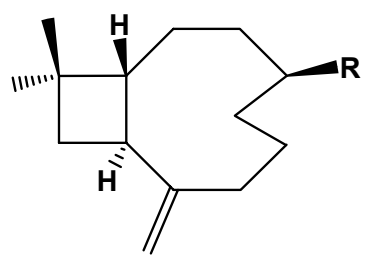

$8 \mathrm{R}=\mathrm{CH}_{2} \mathrm{OH}$ 8a $\mathrm{R}=\mathrm{CH}_{2} \mathrm{OAC}$

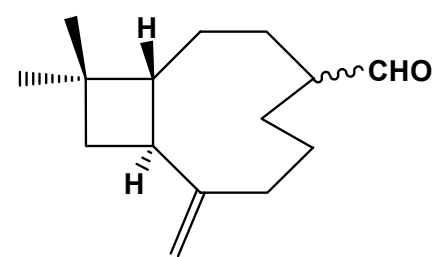

9

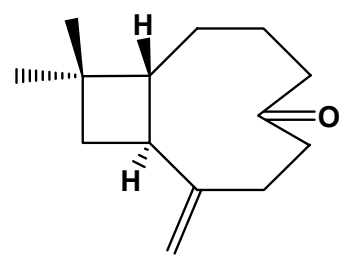

10

Figure 1. Isolated and semi-synthetic new compunds from B. litwinowii.

14-hydroxy-4,5-dihydro- $\beta$-caryophyllene (8) induced $100 \%$ inhibition of the plant pathogenic fungi Cephalosporium aphidicola and Rhizoctonia cerealis at $200 \mu \mathrm{g} / \mathrm{mL}$. This compound was also as active as the antibacterial standard chloramphenicol against Bacillus cereus, with a MIC value of $125 \mu \mathrm{g} / \mathrm{mL}$, but was less active against Escherichia coli, Micrococcus luteus, Staphylococcus aureus, and Pseudomonas aeruginosa. Same compound displayed moderate antifungal activity against Candida glabrata, having a MIC value of 125 $\mu \mathrm{g} / \mathrm{mL}$ when compared to ketoconazole $(62.5 \mu \mathrm{g} / \mathrm{mL}){ }^{15}$

The leaves of five Betula species growing in Turkey, were hydrodistilled and the oil compositions were investigated by GC-MS. 14-Hydroxy- $\beta$-caryophyllene (1) was found as the main constituents $(29.3 \%)$ in the oil of $B$. pendula. 14-Hydroxy-4,5-dihydro- $\beta$-caryophyllene (8) was identified as the main constituents in the oils of $B$. recurvata (25.\%), B. browicziana $(24.8 \%)$ and $B$. litwinowii (18.5\%). Interestingly, in the oil of $B$. medwediewii, methyl salicylate $(49.8 \%)$ was the major constituent. ${ }^{14}$

14-Hydroxy- $\beta$-caryophyllene (1) was found as main compound in the hydrodistilled branch oil of $B$. pendula and B. browicziana (19.8\% and 18.0\%, respectively). 14-Hydroxy-4,5-dihydro$\beta$-caryophyllene (8) was characterized as the main component $B$. recurvata and $B$. litwinowii 
branch oils (22.7 and 19.1\%, respectively). Methyl salicylate $(67.7 \%)$ was identified as a major compound in the oil of B. medwediewii (Table 1).

Various phytopathogenic fungi were evaluated by agar tube dilution method ${ }^{35}$ to test the antifungal activities of the leaf essential oils of $B$. pendula, B. browicziana, B. medwediewii, $B$. recurvata and $B$. litwinowii at $400 \mu \mathrm{g} / \mathrm{mL}$ concentration. Cephalosporium aphidicola, Drechslera sorokiniana, Fusarium solani, Rhizoctonia cerealis, were inhibited, whereas weak activity or no inhibition was observed against Aspergillus quadrilieneatus, A. flavus, Gibberella fujikuroi, Trichoderma harzianum and Trichothecium roseum. ${ }^{14}$ Previous studies demonstrated the antifungal activity of some Betula species; B. alba ${ }^{36}$, B. lenta $^{37}$, B. nigra ${ }^{38}$, B. papyrifera ${ }^{39}$ and B. plathyphylla var. japonica. ${ }^{40}$

In the course of our research into Betula species, we isolated essential oils from the buds of Betula pubescens ssp. pubescens and B. pubescens ssp. czerepanovii naturaly growing in Finland which were analyzed both by GC and GC-MS. 14-Acetoxy- $\beta$-caryophyllene (1a) was determined as the main component in both oils ( 32.5 and $30.0 \%$, respectively). The essential oil was subjected to column chromatography and a bicyclic aldehyde; birkenal (11) and a tricyclic lactone; hushinone (12) were isolated as new compounds. Birkenal (11) was subjected to a mild reduction with $\mathrm{NaBH}_{4}$ to result in birkenol (13). This compound was shown to be naturally present in both essential oils (0.4-0.6\%) with the aid of GC-MS (Table 2). The acetate of this alcohol; birkenyl acetate (13a) was shown to be naturally present at low concentrations $(0.1 \%)$ in both essential oils investigated, as a new natural compound. 6-Hydroxycaryophyllene (14) was also isolated from the oils. Acetylation of this compound resulted in the formation of 6acetoxycaryophyllene (14a) (Figure 2). The new acetate was also detected in the essential oils and identified as such by co-elution by means of TLC and GC-MS. ${ }^{17}$ Recently, Domrachev and Tkachev assigned the absolute configuration of birkenal by chemical correlation with known caryophyllene-type derivatives. ${ }^{41}$

The air-dried buds were hydrodistilled for $3 \mathrm{~h}$ using a Clevenger-type apparatus to yield $5.0 \%$ (A) and 7.8\% (B) of essential oils on a dry-weight basis.

The antioxidant activities of the essential oils from both species and the isolated pure compounds namely; birkenal (11), hushinone (12), birkenol (13), and 6-hydroxycaryophyllene (14) were assessed by measuring their ability to scavenge 1,1-diphenyl-2-picrylhydrazyl radicals $\left(\mathrm{DPPH}^{*}\right)$. The test was performed on the samples at concentrations of 0.5 and $1.0 \mathrm{mg} / \mathrm{mL}$ but scavenging activity of the radicals was not determined. ${ }^{17}$

Other recent work of our group on volatiles of the buds of $B$. pendula obtained by hydrodistillation and microdistillation collected from Germany was reported. The volatiles were analyzed both by GC and GC-MS systems. $\alpha$-Copaene (12\% and 10\%), germacrene D (11\% and $18 \%)$ and $\delta$-cadinene $(11 \%$ and $15 \%)$ were identified as the main constituents in the hydrodistilled and microdistilled samples, respectively. In this study, the essential oil profile of $B$. pendula obtained from the buds (Table 3) was quite different from those of previous investigations and results. ${ }^{13,14,16}$ Kaneko et al. ${ }^{7}$ had reported $\delta$-cadinene $(9.6 \%)$ as the main constituent of $B$. pendula from Japan. However, in other previous studies betulenols were found to be the major constituents in the volatile oil of $B$. pendula. ${ }^{13,14,16,42}$ 
Table 2. Essential oil compositions the buds of $B$. pubescens ssp. pubescens (A) and $B$. pubescens ssp. czerepanovii (B)

\begin{tabular}{|c|c|c|c|}
\hline RRI & Compound & $\mathrm{A}(\%)$ & $\mathrm{B}(\%)$ \\
\hline 1612 & $\beta$-Caryophyllene (3) & 0.3 & 0.7 \\
\hline 1823 & Birkenal (11) & 11.7 & 10.8 \\
\hline 2008 & Caryophyllene oxide & 3.1 & 3.5 \\
\hline 2009 & Birkenyl acetate (13a) & 0.1 & 0.1 \\
\hline 2071 & Humulene epoxide II & 0.4 & 0.5 \\
\hline 2100 & Heneicosane & 1.3 & 0.4 \\
\hline 2149 & Birkenol (13) & 0.4 & 0.6 \\
\hline 2193 & $\beta$-Betulenal (2) & 1.1 & 1.7 \\
\hline 2209 & Hushinone (12) & 0.7 & 0.2 \\
\hline 2210 & 6-Acetoxycaryophyllene (14a) & 5.0 & 1.0 \\
\hline 2272 & 14-Acetoxy- $\beta$-caryophyllene (1a) & 32.5 & 30.0 \\
\hline 2300 & Tricosane & 1.7 & 2.6 \\
\hline 2316 & $\begin{array}{l}\text { Caryophylla-2(12),6(13)-dien-5 } \beta \text {-ol } \\
\text { (=Caryophylladienol I) }\end{array}$ & 1.2 & 1.3 \\
\hline 2324 & $\begin{array}{l}\text { Caryophylla-2(12),6(13)-dien-5a-ol } \\
\text { (=Caryophylladienol II) }\end{array}$ & 5.2 & 5.8 \\
\hline 2329 & 14-Acetoxy- $\alpha$-humulene & 1.2 & 0.7 \\
\hline 2346 & 6-Hydroxycaryophyllene (14) & 11.7 & 15.1 \\
\hline 2357 & 14-Hydroxy- $\beta$-caryophyllene (1) & 1.7 & 3.5 \\
\hline 2617 & 14-Acetoxy-4,5-epoxy- $\beta$-caryophyllene $(\beta \alpha)(\mathbf{6 a})$ & 1.3 & 1.8 \\
\hline 2663 & 14-Hydroxy-4,5-epoxy- $\beta$-caryophyllene $(\beta \alpha)(\mathbf{6})$ & - & 0.2 \\
\hline
\end{tabular}

RRI Relative retention indices calculated against $n$-alkanes

$\%$ : calculated from FID data

tr: trace $(<0.1 \%)$
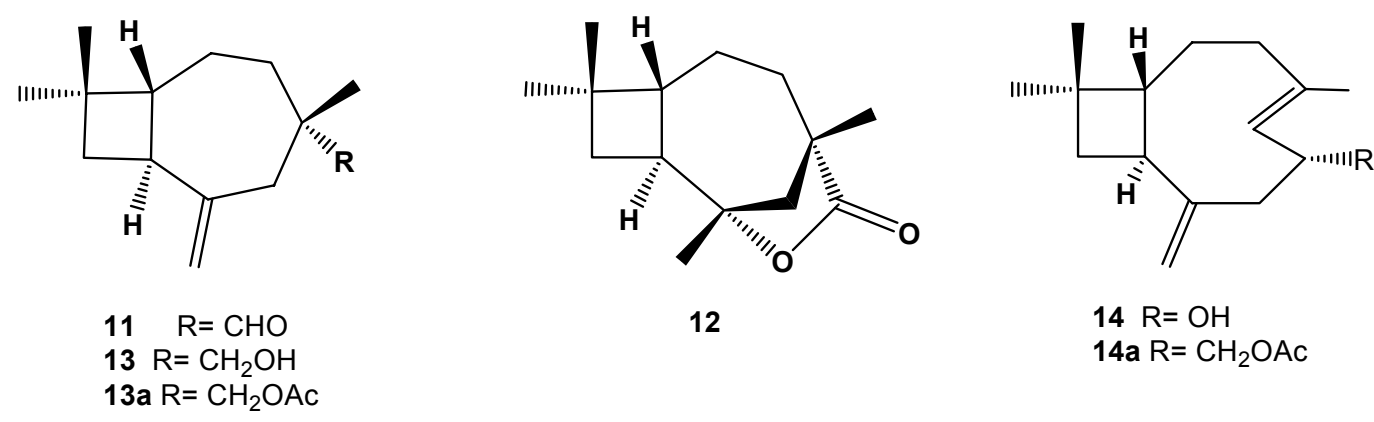

Figure 2. Isolated and semi-synthetic compounds from Betula pubescens. 


\section{Conclusions}

Betula species display an important resource for sesquiterpenes in particular for caryophyllene derivatives. Their biological activity is also worthwhile to investigate as in in vitro pre-screens we have observed antimicrobial activity against various human and plant pathogens. Another interesting aspect of sesquiterpenes and caryophyllenes is the potential use in flavour and fragrance industries, however, the mentioned secondary metabolites need to be investigated further from this aspect.

\section{Experimental Section}

Plant material. Leaf, branch and buds of B. pendula, B. browicziana, B. litwinowii, B. recurvata and $B$. medwediewii were collected from different localities in North Eastern region of Turkey. Voucher specimens are kept at the Herbarium of the Faculty of Pharmacy of Anadolu University in Eskişehir, Turkey (ESSE). Detailed information on the plant materials used are given in Table 4. Buds of $B$. pubescens ssp. czerepanovii and B. pubescens ssp. pubescens were collected in April 2002 from the Botanical Garden of the University of Turku (SW Finland). Voucher specimens of the buds have been deposited in the Turku University Herbarium under numbers TUR 573172 and TUR 573171, respectively. Buds of B. pendula growing in Germany, were collected from Maxhütte, Regensburg in April 2002.

The plant materials were either hydrodistilled using a Clevenger type apparatus or were subjected to Likens-Nickerson simultaneous distillation-extraction (SDE) method and Microdistillation method when the plant material amounts were insufficient. The essential oils were analysed by GC and GC-MS.

\section{Isolation of the essential oils}

Hydrodistillation. The plant materials were subjected to hydrodistillation for $3 \mathrm{~h}$ using a Clevenger-type apparatus to produce the essential oils. The percentage (\%) yields were calculated on dry weight basis after drying over anhydrous $\mathrm{Na}_{2} \mathrm{SO}_{4}$.

Likens-Nickerson distillation-extraction method. B. browicziana and B. recurvata $(1.0 \mathrm{~g}$ of buds) were subjected to SDE for 1 hour using a Likens-Nickerson apparatus with $1 \mathrm{ml}$ of $n$ hexane as solvent.

Microdistillation. The plant material $(\sim 200 \mathrm{mg})$ was placed in the sample vial of the MicroDistiller ${ }^{\circledR}$ (Eppendorf, Germany) system together with $10 \mathrm{ml}$ of distilled water. $\mathrm{NaCl}(2.5$ g) and water $(0.5 \mathrm{ml})$ were added into the collection vial to break any possible emulsion formation. $n$-Hexane $(300 \mu \mathrm{l})$ was also added into the collecting vial to trap the volatile components. The sample vial was heated to $100^{\circ} \mathrm{C}$ at a rate of $20^{\circ} \mathrm{C} / \mathrm{min}$ and then kept at $100^{\circ} \mathrm{C}$ for $15 \mathrm{~min}$. It was then heated to $112^{\circ} \mathrm{C}$ at a rate of $20^{\circ} \mathrm{C} / \mathrm{min}$ and kept at this temperature for 35 min. Later, the sample was subjected to post-run for 2 min under the same conditions. The collecting vial was cooled to $-5^{\circ} \mathrm{C}$ during the distillation. After the distillation was completed the $n$-hexane-trapped volatiles were analyzed by both by GC and GC-MS. 
Table 3. Main components of Betula pendula buds growing in Germany

\begin{tabular}{|c|c|c|c|}
\hline RRI & Compound & Hydrodistillation & Microdistillation \\
\hline 1400 & Nonanal & 0.9 & $\operatorname{tr}$ \\
\hline 1466 & $\alpha$-Cubebene & 0.8 & 0.5 \\
\hline 1493 & $\alpha$-Ylangene & 1.1 & 0.7 \\
\hline 1497 & $\alpha$-Copaene & 11.8 & 9.6 \\
\hline 1549 & $\beta$-Cubebene & 0.7 & 0.5 \\
\hline 1589 & $\beta$-Ylangene & 1.3 & 0.4 \\
\hline 1597 & $\beta$-Copaene & 1.0 & 0.5 \\
\hline 1612 & $\beta$-Caryophyllene (3) & 3.4 & 3.2 \\
\hline 1617 & 6,9-Guaiadiene & 2.4 & 1.9 \\
\hline 1628 & Aromadendrene & 0.6 & 0.3 \\
\hline 1661 & Alloaromadendrene & 2.2 & 2.2 \\
\hline 1677 & epi-Zonarene & 0.6 & 0.6 \\
\hline 1687 & $\alpha$-Humulene & 2.9 & 3.0 \\
\hline 1704 & $\gamma$-Muurolene & 2.6 & 3.0 \\
\hline 1726 & Germacrene D & 11.4 & 18.0 \\
\hline 1740 & $\alpha$-Muurolene & 2.0 & 2.5 \\
\hline 1773 & $\delta$-Cadinene & 10.8 & 15.3 \\
\hline 1776 & $\gamma$-Cadinene & 2.4 & 4.0 \\
\hline 1810 & 3,7-Guaiadiene & 0.5 & 0.7 \\
\hline 1941 & $\alpha$-Calacorene & 0.7 & 0.5 \\
\hline 2008 & Caryophyllene oxide & 0.5 & 0.7 \\
\hline 2071 & Humulene epoxide-II & 0.5 & 0.6 \\
\hline 2080 & Cubenol & 2.7 & 0.6 \\
\hline 2088 & 1-epi-Cubenol & 5.0 & 1.4 \\
\hline 2109 & Furopelargone B & 0.9 & 1.4 \\
\hline 2187 & T-Cadinol & 1.5 & 3.4 \\
\hline 2209 & T-Muurolol & 0.9 & 1.7 \\
\hline 2219 & $\delta$-Cadinol & 0.4 & 0.7 \\
\hline 2255 & $\alpha$-Cadinol & 2.8 & 5.8 \\
\hline 2300 & Tricosane & 0.5 & 0.3 \\
\hline 2369 & Eudesma-4(15),7-dien-1 $\beta$-ol & 0.1 & 0.7 \\
\hline 2500 & Pentacosane & 1.6 & 2.8 \\
\hline
\end{tabular}

RRI: Relative retention indices calculated against $n$-alkanes

$\%$ : calculated from FID data

tr: Trace $(<0.1 \%)$

The plant material was hydrodistilled for $3 \mathrm{~h}$ using a Clevenger type apparatus. The essential oil yield was calculated on dry weight basis corresponding to $0.5 \%$. 
Table 4. Information on the Betula species growing in Turkey and essential oils

\begin{tabular}{|c|c|c|c|c|c|c|}
\hline $\begin{array}{c}\text { Betula } \\
\text { species }\end{array}$ & Collection Site & $\begin{array}{c}\text { Altitude } \\
\text { (m) }\end{array}$ & $\begin{array}{c}\text { Collection } \\
\text { Period }\end{array}$ & Parts & $\begin{array}{c}\text { Oil Yield* } \\
(\%)\end{array}$ & ESSE \\
\hline \multirow[t]{3}{*}{ browicziana } & Rize - Çamlıhemşin & 1765 & 07.1996 & Branch & 0.15 & 12239 \\
\hline & Rize - Çamlıhemşin & 1765 & 07.1996 & Leaf & 0.11 & 12239 \\
\hline & Rize - Çamlıhemşin & 1765 & 05.1998 & Bud & \# & 12760 \\
\hline \multirow[t]{3}{*}{ litwinowii } & Artvin - Hatila valley & 2050 & 07.1998 & Branch & 0.01 & 12755 \\
\hline & Artvin - Hatila valley & 2050 & 07.1998 & Leaf & 0.17 & 12755 \\
\hline & Artvin - Hatila valley & 2050 & 05.1998 & Bud & 6.34 & 12757 \\
\hline \multirow[t]{3}{*}{ medwediewii } & Rize - Çamlıhemşin & 1700 & 05.1998 & Branch & 0.1 & 12759 \\
\hline & Rize - Çamlıhemşin & 1700 & 06.1998 & Leaf & 0.13 & 12563 \\
\hline & Rize - Çamlıhemşin & 1700 & 05.1998 & Bud & 1.25 & 12759 \\
\hline \multirow[t]{3}{*}{ pendula } & Erzurum & 1800 & 05.1998 & Branch & 0.1 & 12527 \\
\hline & Erzurum & 1800 & 05.1998 & Leaf & 0.63 & 12527 \\
\hline & Erzurum & 1800 & 05.1998 & Bud & 3.82 & 12527 \\
\hline \multirow[t]{3}{*}{ recurvata } & Rize - Çamlıhemşin & $1700-1800$ & 06.1998 & Branch & $* *$ & 12534 \\
\hline & Rize - Çamlıhemşin & $1700-1800$ & 06.1998 & Leaf & 0.56 & 12534 \\
\hline & Rize - Çamlıhemşin & 1700 & 09.1998 & Bud & $\#$ & 12758 \\
\hline
\end{tabular}

*Yields are given on moisture free basis

** Due to the poor yield of oil, it was dissolved in $n$-hexane.

\# Likens-Nickerson SDE

\section{Analysis of the essential oils}

Gas chromatography (GC). Betula essential oils were analyzed by GC using a Hewlett Packard 6890 system and an HP Innowax FSC column (60 m x $0.25 \mathrm{~mm} \varnothing$, with $0.25 \mu \mathrm{m}$ film thickness) was used with nitrogen at $1 \mathrm{~mL} / \mathrm{min}$. Initial oven temperature was $60^{\circ} \mathrm{C}$ for $10 \mathrm{~min}$, and increased at $4^{\circ} \mathrm{C} / \mathrm{min}$ to $220^{\circ} \mathrm{C}$, then constant at $220^{\circ} \mathrm{C}$ for $10 \mathrm{~min}$ and increased at $1{ }^{\circ} \mathrm{C} / \mathrm{min}$ to $240^{\circ} \mathrm{C}$. Injector temperature was set at $250^{\circ} \mathrm{C}$. Percentage composition of the individual components were obtained from electronic integration using flame ionization detection (FID) at $250^{\circ} \mathrm{C}$. $n$-Alkanes were used as reference points in the calculation of relative retention indices (RRI). Relative percentages of the characterized components were as cited in Table 1-3.

Gas chromatography-mass spectrometry (GC-MS). GC-MS analysis was performed with a Hewlett-Packard GCD, system and Innowax FSC column $(60 \mathrm{~m}$ x $0.25 \mathrm{~mm} \varnothing, 0.25 \mu \mathrm{m}$ film thickness) was used with Helium. GC oven temperature conditions were as described above, split flow was adjusted at $50 \mathrm{~mL} / \mathrm{min}$, the injector temperature was at $250^{\circ} \mathrm{C}$. Mass spectra were recorded at $70 \mathrm{eV}$. Mass range was from $m / z 35$ to 425 .

Identification of components. Identification of the essential oil components were carried out by comparison of individual relative retention times with those of authentic samples or by comparison of their relative retention index (RRI) to series of $n$-alkanes. Computer matching against commercial (Wiley and MassFinder 2.1) and in-house "Baser Library of Essential Oil Constituents" libraries made up by genuine compounds and components of known oils, as well as MS literature data was also used for the identification. 


\section{References}

1. Heywood,V. H. In Flowering Plants of the World, Oxford University Press: Oxford, 1979; p 59.

2. Davis, P. H. Flora of Turkey and the East Aegean Islands, Vol. 7. Edinburgh University Press: Edinburgh, 1982; p 688.

3. Davis, P. H.; Mill, R. R.; Tan, K. Flora of Turkey and the East Aegean Island, Vol. 10. Edinburgh University Press, Edinburgh, 1988, p 215.

4. Wichtl, M. In Herbal Drugs and Phytopharmaceuticals; Bisset, N. G.; Ed.; Medpharm Sci. Pub.: Stuttgart, 1994; p 106.

5. Guenther, E. The Essential Oils, Vol. 2., Robert E. Krieger, Publishing Co.: Huntington, New York, 1975; p 264.

6. Lawless, J. The Encyclopaedia of Essential Oils, Element Books Ltd: Longmead, 1992; p 59.

7. Kaneko, N.; Ishii, H.; Sato, A.; Kanisawa, T.; Watanabe, S. $12^{\text {th }}$ International Congress of Flavours, Fragrances and Essential Oils. Proceedings, Woidich, H.; Buchbauer, G.; Ed.; Fachzeitschriftverlag-GmbH: Vienna, 1992; p 53.

8. Treibs, W.; Lossner, G. Justus Liebigs Ann. Chem. 1960, 634, 124.

9. Holub, M.; Herout, V.; Horak, M.; Sorm, F. Collec. Czech. Chem. Commun. 1959, 24, 3730.

10. Dhar, D. N.; Srivastava, R. K.; Nanda, R. K. The Eastern Pharmacist 1970, 13, 127.

11. Hiltunen, R.; Vaisanen, L.; Forsen, K.; Schantz von M. Acta Pharm. Fenn. 1983, 92, 137.

12. Stepen, R. A.; Khan, V.A.; Vershnyak, V. M.; Peryshkina, G. I. Chem. Nat. Comp. 1987, 6, 666.

13. Demirci, B.; Baser, K. H. C.; Ozek, T.; Demirci, F. Planta Med. 2000, 66, 490.

14. Demirci, F.; Demirci, B.; Baser, K. H. C.; Guven, K. Khim. Prir. Soedin. 2000, 36, 126.

15. Demirci, B.; Baser, K. H. C.; Demirci, F.; Hamann, M. T. J. Nat. Prod. 2000, 63, 902.

16. Demirci, B.; Baser, K. H. C. Flav. Fragr. J. 2003, $18,87$.

17. Klika, K. D.; Demirci, B.; Salminen, J. P.; Ovcharenko, V.V.; Vuorela, S.; Baser, K. H. C.; Pihlaja, K. Eur. J. Org. Chem. 2004, 2627.

18. Demirci, B.; Paper, D. H.; Demirci, F.; Baser, K. H. C.; Franz, G. Evidence-based Complementary and Alternative Medicine 2004, 1, 301.

19. Collado, I. G.; Hanson, J. R.; Macias-Sanchez, A. Nat. Prod. Rep. 1998, 15, 187.

20. Tkachev, A. V. Chem. Nat. Comp. 1987, 4, 393.

21. Fraga, B. M. Nat. Prod. Rep. 2006, 23, 943.

22. Collado, I. G.; Hanson, J. R.; Macías-Sánchez, A. J. Nat. Prod. Rep. 1998, 15, 187.

23. Barrero, A. F.; Molina, J.; Oltra, J. E.; Altarejos, J.; Barragan, A.; Lara, A.; Segura, M. Tetrahedron 1995, 51, 3813.

24. Macleod, J. K.; Rasmussen, H. B. Phytochemistry 1999, 50, 105.

25. Hinkley, S. F. R.; Perry, N. B.; Weavers, R. T. Tetrahedron Lett. 1994, 35, 3775.

26. Manns, D.; Hartmann, R. Planta Med. 58, 1992, 442.

27. Barrero, A. F.; Oltra, J. E.; Altarejos, J.; Barragan, A.; Lara, A. Flav. Fragr. J. 1993, 8, 185. 
28. Hiede, R.; Visser, J.; Linde, L. M.; Lier, F. P. Flavour and Fragrance: A World perspective, Ed. Lawrence, B. M.; Mookherjee, B. D.; Willis, B. J. Elsevier Science Pub., Amsterdam, 1988, p 627.

29. Kaiser, R.; Lamparsky, D. Helv. Chim. Acta. 1983, 66, 1843.

30. Nabotada, K.; Hiroshi, I.; Ikuko, M.; Sadamoto, W. Kokai Tokkyo Kohu, JP 0356, 410 (9156,410) (CI.A61K7/16) 1991; Chem. Abs. 1991, 115, 286919.

31. Recio, M. C.; Rios, J. L.; Villar, A. Phytotherapy Res. 1989, 3, 77.

32. McCutcheon, A. R.; Ellis, S. M.; Hancock, R. E. W.; Towers, G. H. N. J. Ethnopharmacol. 1992, 37, 213.

33. Brantner, A.; Grein, E. J. Etnopharmacol. 1994, 44, 35.

34. Dornberger, K.; Leich, H. Pharmazie 1982, 37, 215.

35. Paxton, J. D. Methods in Plant Biochemistry, Vol. 6, Ed.Hostettman, K. Academic Press, London, 1991; p 37.

36. Recio, M. C.; Rios, J. L.; Villar, A. Phytotherapy Res. 1989, 3, 77.

37. Maruzzella, J.C.; Balter, J. Plant Dis. Reptr. 1959, 43, 1143; Chem. Abs.: 1960, 54,11136.

38. McChesney, J. D.; Adams, R. P. Econ. Bot. 1985, 39, 74.

39. McCutcheon, A. R.; Ellis, S. M.; Hancock, R. E. W.; Towers, G. H. N. J. Ethnopharmacol. 1994, 44, 157.

40. Yokotha, N.; Zenda, H.; Kosuge,T.; Yamamoto, T.; Torigoe, Y. Yakugaku Zasshi, 1978, 98, 1607; Chem. Abs. 1979, 90,135083.

41. Domrachev, D. V.; Tkachev, A. V. Chem. Nat. Comp. 2006, 42, 304.

42. Vershnyak, V. M.; Stepen, R. A. Rastitel'nye Resursy 1992, 28, 86. 